\title{
Genes Conferring Sensitivity to Stagonospora nodorum Necrotrophic Effectors in Stagonospora Nodorum Blotch-Susceptible U.S. Wheat Cultivars
}

Matthew Bertucci, United States Department of Agriculture-Agricultural Research Service (USDA-ARS), Department of Plant Pathology, North Carolina State University, Raleigh 27695; Gina Brown-Guedira, Department of Crop Science, North Carolina State University, Raleigh 27695; J. Paul Murphy, USDA-ARS, Department of Crop Science, North Carolina State University, Raleigh 27606; and Christina Cowger, USDA-ARS, Department of Plant Pathology, North Carolina State University, Raleigh 27695

\begin{abstract}
Bertucci, M., Brown-Guedira, G., Murphy, J. P., and Cowger, C. 2014. Genes conferring sensitivity to Stagonospora nodorum necrotrophic effectors in Stagonospora nodorum blotch-susceptible U.S. wheat cultivars. Plant Dis. 98:746-753.

Stagonospora nodorum is a necrotrophic fungal pathogen that causes Stagonospora nodorum blotch (SNB), a yield- and quality-reducing disease of wheat. $S$. nodorum produces a set of necrotrophic effectors (NEs) that interact with the products of host sensitivity genes to cause cell death and increased susceptibility to disease. The focus of this study was determination of NE sensitivity among 25 winter wheat cultivars, many of them from the southeastern United States, that are susceptible to SNB, as well as the moderately resistant 'NC-Neuse'. Thirty-three isolates of $S$. nodorum previously collected from seven southeastern U.S. states were cultured for NE production, and the culture filtrates were used in an infiltration bioassay. Control strains of

Pichia pastoris that expressed SnToxA, SnToxl, or SnTox3 were also used. All SNB-susceptible cultivars were sensitive to at least one NE, while NC-Neuse was insensitive to all NEs tested. Among the sensitive lines, $32 \%$ contained sensitivity gene $T s n 1$ and $64 \%$ contained sensitivity gene Snn3. None were sensitive to SnTox1. Additionally, 10 molecular markers for sensitivity genes Tsn1, Snn1, Snn2, and Snn3 were evaluated for diagnostic potential. Only the marker Xfcp623 for Tsn1 was diagnostic, and it was in perfect agreement with the results of the infiltration bioassays. The results illuminate which NE sensitivity genes may be of concern in breeding for resistance to SNB in the southeastern United States.
\end{abstract}

Stagonospora nodorum blotch (SNB) is a yield- and quality-reducing disease of wheat (Triticum aestivum) that occurs ubiquitously in the eastern and, especially, the southeastern United States $(5,27)$. SNB is caused by the necrotrophic fungal pathogen Stagonospora nodorum, a well-studied model organism for the class Dothideomycetes (24). When environmental conditions favor disease, SNB can cause yield losses up to $31 \%$ in susceptible wheat varieties (5).

Symptoms of SNB arise as small necrotic lesions surrounded by a chlorotic halo at the site of infection (27). Symptoms are found most commonly on the leaves and glumes but can occur on any aerial part of the plant (8). As disease progresses, lesions expand to form large necrotic patches. The pathogen produces multiple generations in a growing season, spreading upward in the canopy via rain-splashed pycnidiospores (8) and spreading long distances via wind-blown ascospores $(2,28)$.

$S$. nodorum utilizes a set of proteinaceous necrotrophic effectors (NEs), also known as host-selective toxins, that have been shown to increase severity of disease $(1,11,13,15,17,22,23)$. The NEs interact with the host in an inverse gene-for-gene manner: products of sensitivity genes in the host recognize the effectors produced by the fungus and trigger a hypersensitive response, leading to increased susceptibility in the field (11). Each NE produced by $S$. nodorum is recognized by at least one sensitivity gene in wheat $(12,13)$. The best-characterized sensitivity gene, $T s n 1$, codes for a nucleotide-binding site leucine-rich repeat class of protein, typical of those encoded by resistance genes in plant defense against pathogens and some pests (3). SnToxA, the NE that interacts spe-

Corresponding author: M. Bertucci, E-mail: mbbertuc@ncsu.edu

Accepted for publication 22 November 2013.

http://dx.doi.org/10.1094/PDIS-08-13-0820-RE

This article is in the public domain and not copyrightable. It may be freely reprinted with customary crediting of the source. The American Phytopathological Society, 2014. cifically with the product of $T s n 1$, was originally identified in Pyrenophora tritici-repentis, the cause of tan spot of wheat. Tan spot occurs infrequently in the southeastern United States; SNB is the dominant foliar and glume blotch pathogen in that region $(\mathrm{C}$. Cowger, personal observation), and, thus, was the focus of this study.

Development of SNB is dependent on environmental factors, including temperature and moisture $(4,8,32)$, that are unpredictable. Wheat cultivars are most reliably evaluated for SNB resistance in field nurseries with artificial conditions that enhance disease development (6). It is possible that cultivars selected in the absence of SNB pressure could have been inadvertently selected for susceptibility to SNB, due to the hypothesized pleiotropy of NE sensitivity and resistance to other pathogens or pests (14). Indeed, many advanced experimental wheat lines show high levels of susceptibility when tested in the United States Department of AgricultureAgricultural Research Service (USDA-ARS) Eastern United States Septoria Nursery (Raleigh and Kinston, NC), where SNB pressure is uniform and adequate to separate performance of varieties (C. Cowger, personal observation).

The majority of wheat grown in the southeastern United States is soft wheat, useful for cookies and pastries but not for bread. Recently, some southeastern U.S. wheat breeders have established hard wheat programs aimed at producing bread wheats for local markets. Lines developed in the Great Plains region of the United States have been used for crossing to introgress greater hardness. For the most part, these hard wheat cultivars were not selected for SNB resistance, and many are highly susceptible to SNB in the field (C. Cowger, personal observation). Field susceptibility to SNB has been linked to sensitivity to NEs (11). SnTox3 sensitivity was found in a large majority of western Australian wheat cultivars (33). It was uncertain prior to this study which NEs might be contributing to the susceptible phenotypes that have been observed in the southeastern United States.

Because NEs are thought to play a major role in disease development, this study sought to determine which sensitivity genes were most prevalent in widely planted or representative SNB-susceptible wheat germplasm in the southeastern United States. Field 
susceptibility data were available on some elite experimental materials, and pedigree information was also used to identify parents common to susceptible experimental lines. By conducting infiltration experiments with multiple $S$. nodorum isolates collected from across the region and with NE-producing Pichia pastoris yeast controls, we sought to determine which of the reported NEs contribute to susceptibility of winter wheat cultivars to SNB in the southeastern United States.

In addition, the sensitivity genes in wheat have been identified and mapped to narrow regions in the wheat genome $(12,13,24)$. Available molecular markers for sensitivity genes were evaluated for diagnostic potential by comparing the genotype and phenotype of the selected cultivars. The markers were identified by Dr. Justin Faris (USDA-ARS, Fargo, ND) and colleagues in the hard red spring wheat BG population (BR34 $\times$ Grandin), and an additional goal of this research was their cross-validation in winter wheat germplasm for potential use in marker-assisted selection (MAS) in the southeastern United States.

\section{Materials and Methods}

Fungal materials. In a previous study by Crook et al. (7), $39 \mathrm{~S}$. nodorum isolates were collected from wheat debris in seven states in the southeastern United States. Of that collection, 33 isolates were used for infiltrations in the present study: 5 from Arkansas, 5 from Georgia, 1 from Maryland, 10 from North Carolina, 4 from South Carolina, 4 from Tennessee, and 4 from Virginia. Each isolate was presumed to be a different genetic individual that could potentially produce a different NE or effectors in culture. Additionally, three North Dakota $S$. nodorum isolates kindly supplied by Dr. Tim Friesen (USDA-ARS, Fargo, ND) were included due to their known NE production: Sn4 (19), Sn6 (15,19), and Sn2000 (18). Sn4 reportedly produces SnToxA, SnTox1, SnTox2, and SnTox3 in culture (19); Sn6 produces SnToxA, SnTox1, SnTox2 (15), and SnTox3 (19); and Sn2000 was used as a control for production of SnToxA (16), SnTox1 (18,23), and, most recently, SnTox5 (13). All isolates were maintained on V8-potato dextrose agar (PDA) plates at $4^{\circ} \mathrm{C}$ until use in infiltrations. Long-term storage of cultures was achieved by placing mycelial plugs in $80 \%$ glycerol and storing them at $-80^{\circ} \mathrm{C}$.

Transformed $P$. pastoris yeast strains, also supplied by Dr. Friesen, were used as controls for NE production and infiltration. These strains were engineered for heterologous gene expression of one NE each: SnToxA (16), SnTox1 (20), or SnTox3 (19). For long-term storage, cells of $P$. pastoris strains were suspended in $80 \%$ glycerol and stored at $-80^{\circ} \mathrm{C}$.

Plant materials. In total, 32 wheat cultivars were selected for screening: 26 cultivars that were the subject of this experiment and 6 controls with known sensitivity genes (Table 1). The cultivars of interest were either susceptible to SNB in the field or were found in the pedigree of multiple susceptible cultivars. Among these cultivars were commercial soft red winter wheat cultivars from the southeastern United States, such as 'AGS2000', 'Magnolia', and 'Pembroke'. Also included were hard red winter wheat 'Jagger', 'Siouxland', and 'Trego' that have been used to introgress grain hardness and bread-baking quality into mid-Atlantic U.S. bread wheat germplasm. These cultivars have attractive traits such as leaf rust resistance or grain hardness, and each has also shown high SNB susceptibility in the field. Some of the cultivars tested are used in U.S. breeding programs for disease resistance; for example, the CIMMYT spring wheat 'Pavon 753', which possesses Lr47, a gene for resistance to leaf rust (caused by Puccinia triticina). Altogether, the cultivars of interest included 14 commercial cultivars and 12 elite experimental lines. Only one was known to be moderately resistant in the field: 'NC-Neuse', a commercial soft red winter wheat cultivar.

Control cultivars were 'Grandin', 'BR34', 'Chinese Spring', 'BG-223', 'BG-220', and 'BG-261'. Grandin and BR34 were rated susceptible and resistant to SNB, respectively (11). Grandin was sensitive to SnToxA (16), SnTox2 (15), and SnTox3(17), while BR34 was insensitive. These two cultivars were used in North
Dakota as parents of the BG population (21), a series of recombinant inbred lines (RILs) segregating for sensitivity to NEs. BG261, BG-223, and BG-220 were three of those RILs with sensitivity to SnToxA (16), SnTox2 (15), and SnTox3 (17), respectively. Chinese Spring, an introduction from Chinese White, a landrace from China, was sensitive to SnTox1 $(23,25)$.

Seedling growth conditions. Wheat cultivars were planted in 2M lightweight mix (Conrad Fafard, Inc.) in RLC4 cone-tainers (Stuewe and Sons Inc.). Plants were watered from the bottom by placing cone-racks in a water-filled basin that was refilled as necessary. The plants were grown in a greenhouse with an average temperature of $22^{\circ} \mathrm{C}$ or in a growth chamber at $21^{\circ} \mathrm{C}$ with a $12-\mathrm{h}$ photoperiod, until plants reached the two- to three-leaf stage (14 to 17 days).

For infiltration trials, the cones were arranged using a randomized block design with three replications across a 10-by-10-cone rack. The experimental unit was the planting cone, and each cone contained one plant of a single cultivar. All trials included the experimental cultivars to be tested as well as the control cultivars for sensitivity. Trials were repeated for seed that failed to germinate, and also for lines or cultivars that were included later in the experiment ('ARS 12-532', 'ARS 12-533', 'ARS 12-534', Chinese Spring, and NC-Neuse). In repeated trials, planting cones were randomized and all controls were included.

Culture filtrate production. S. nodorum isolates were grown for 14 days on V8-PDA plates in a growth chamber at $26^{\circ} \mathrm{C}$ with a 12 -h photoperiod. The plates were stored at $4^{\circ} \mathrm{C}$ for up to 3 months. For liquid cultures, four to six mycelial cuttings totaling approximately $2 \mathrm{~cm}^{2}$ were added to a $250-\mathrm{ml}$ Erlenmeyer flask containing $75 \mathrm{ml}$ of Fries medium (18). The flasks were wrapped in aluminum foil to shield them from light, and were shaken at 80 $\mathrm{rpm}$ for $48 \mathrm{~h}$. The liquid cultures were then placed in a dark drawer for three weeks of stationary growth at room temperature $\left(20^{\circ} \mathrm{C}\right)$.

Pichia pastoris controls were grown on yeast peptone dextrose (YPD) agar media at $27^{\circ} \mathrm{C}$ for 48 to $72 \mathrm{~h}$, and stored at $4{ }^{\circ} \mathrm{C}$ for up to 3 months. To prepare liquid cultures, a single colony from a YPD plate was added to $1 \mathrm{ml}$ of YPD broth. The 1-ml culture was shaken at $220 \mathrm{rpm}$ at $30^{\circ} \mathrm{C}$ for $48 \mathrm{~h}$. Then, $200 \mu \mathrm{l}$ of the $1-\mathrm{ml} \mathrm{cul-}$ ture was added to a vial containing $10 \mathrm{ml}$ of fresh YPD broth. The $10-\mathrm{ml}$ culture was then shaken at $220 \mathrm{rpm}$ at $30^{\circ} \mathrm{C}$ for $48 \mathrm{~h}$.

Culture filtrates (CFs) of $S$. nodorum isolates were collected by passing liquid cultures through a series of filters. Each 75-ml liquid culture was filtered through a Whatman number 1 filter paper (Whatman PLC) by vacuum filtration, using a Büchner funnel and vacuum flask (Corning Inc.). The collected filtrate was drawn into a $60-\mathrm{ml}$ syringe and filtered through a $0.80-\mu \mathrm{m}$ Luer-lock filter tip (Corning Inc.). The remaining filtrate was again drawn into a 60$\mathrm{ml}$ syringe and filtered through a $0.45-\mu \mathrm{m}$ Luer-lock filter tip (Corning Inc.). The $\mathrm{CF}$ was then used for infiltrations or stored at $4^{\circ} \mathrm{C}$ for up to $24 \mathrm{~h}$.

For $P$. pastoris controls, the $10-\mathrm{ml}$ cultures were decanted carefully, leaving behind the majority of yeast sediment, then drawn into a $30-\mathrm{ml}$ syringe and passed through a $0.45-\mu \mathrm{m}$ Luer-lock filter tip. The $\mathrm{CF}$ was then used for infiltrations or stored at $4^{\circ} \mathrm{C}$ for up to $24 \mathrm{~h}$.

Infiltration assays. Each plant was infiltrated with CFs from either the P. pastoris controls or the $S$. nodorum isolates. Infiltrations were performed with a 3-ml needleless syringe (Becton, Dickinson and Co.). The secondary leaf was held taut between the thumb and forefinger of one hand. With the other hand, the syringe tip was pressed against the leaf tissue and the plunger depressed until 2 to $3 \mathrm{~cm}$ of leaf surface was infiltrated (approximately $50 \mu \mathrm{l}$ ). The infiltrated region was then marked using a nontoxic felt-tip pen. Infiltrated plants were placed in a Percival growth chamber at $21^{\circ} \mathrm{C}$ with a 12-h photoperiod.

Sensitivity of wheat seedlings to NEs contained in CFs was scored visually 3,5 , and 7 days post infiltration, using a scale with three levels: insensitive (-), indicating that no tissue was discolored and the leaf remained healthy; chlorotic (y), indicating yellowing of tissue within the infiltrated region, with some green tissue still 
visible; and necrotic (+), indicating complete necrosis and leaf folding within the infiltrated region (Fig. 1). Ratings applied only to the infiltrated area marked by the felt-tip pen. Cultivars with chlorotic or necrotic ratings were considered "sensitive" for purposes of this analysis. Only scores from 7 days post infiltration were used in the final analysis and results of each trial were recorded as the majority score of three infiltrated replicate plants. If the three replicates were all different, the cultivar-isolate combination was repeated until one phenotype had a majority.

Molecular markers. DNA was extracted from leaf tissue of each wheat cultivar using a modified protocol for T. aestivum extraction (29). DNA was diluted with sterile $\mathrm{H}_{2} \mathrm{O}$ to a final concen- tration of $40 \mathrm{ng} / \mu \mathrm{l}$ for use in polymerase chain reaction $(\mathrm{PCR})$ amplification. The DNA was stored in sealed freezer plates at $4^{\circ} \mathrm{C}$ until needed. Primer sets were selected for 10 molecular markers reported for Tsn1, Snn1, Snn2, and $S n n 3$ (Table 2). Almost all were simple-sequence repeats (SSRs) reported to be linked to the sensitivity genes. The markers were evaluated for diagnostic potential for their respective sensitivity genes in the germplasm chosen for the current study.

Polymerase chain reactions contained $1 \times \mathrm{NH}_{4}$ buffer, $2.0 \mathrm{mM}$ $\mathrm{MgCl}_{2}, 312.5 \mu \mathrm{M} \mathrm{dNTP}, 0.3 \mu \mathrm{M}$ forward primer, $0.3 \mu \mathrm{M}$ reverse primer, DNA at $40 \mathrm{ng} / \mu \mathrm{l}$, and $1 \mathrm{U}$ of Biolase Taq polymerase. Each reaction was a total of $20 \mu \mathrm{l}$. The number of cycles and annealing

Table 1. Wheat cultivars evaluated for necrotrophic effector (NE) sensitivity due to susceptibility to Stagonospora nodorum blotch (SNB) or presence in pedigrees of susceptible wheat cultivars and control cultivars

\begin{tabular}{|c|c|c|c|c|c|c|c|}
\hline \multirow[b]{2}{*}{ Cultivar ${ }^{\mathrm{a}}$} & \multirow[b]{2}{*}{ ID No. ${ }^{b}$} & \multirow[b]{2}{*}{ Pedigree } & \multirow[b]{2}{*}{ Breeder } & \multirow{2}{*}{$\begin{array}{l}\text { Market } \\
\text { class }^{\mathrm{c}}\end{array}$} & \multirow[b]{2}{*}{ Test $^{\mathrm{d}}$} & \multicolumn{2}{|c|}{ Ratinge $^{\mathrm{e}}$} \\
\hline & & & & & & Leaves & Glumes \\
\hline \multicolumn{8}{|c|}{ Unknown sensitivities } \\
\hline AGS 2000 & PI 612956 & Pioneer-2555/PF-84301//FL-302 & Univ. Georgia & SRW & 2009-10 ESN & 6.0 & 1.0 \\
\hline ARS $12-532$ & Exp. & TX98D2334/TX95D8009//TX99D4612/TAM302 & $\begin{array}{l}\text { USDA-ARS } \\
\text { Raleigh }\end{array}$ & S/H RW & Breeder's nursery & \multicolumn{2}{|c|}{ Very susceptible } \\
\hline ARS $12-533$ & Exp. & TX98D2334/TX95D8009//TX99D4612/TAM302 & $\begin{array}{l}\text { USDA-ARS } \\
\text { Raleigh }\end{array}$ & S/H RW & Breeder's nursery & \multicolumn{2}{|c|}{ Intermediate } \\
\hline ARS $12-534$ & Exp. & TX98D2334/TX95D8009//TX99D4612/TAM302 & $\begin{array}{l}\text { USDA-ARS } \\
\text { Raleigh }\end{array}$ & S/H RW & Breeder's nursery & \multicolumn{2}{|c|}{ Flecking reaction } \\
\hline ARS05-0242 & Exp. & $\begin{array}{l}\text { Coker9835/RL6042//TX99D4657 } \\
\text { (WX02ARS030-591-25) }\end{array}$ & $\begin{array}{l}\text { USDA-ARS } \\
\text { Raleigh }\end{array}$ & HRW & 2007-08 ESN & 4.7 & 6.3 \\
\hline $\begin{array}{l}\text { GA 001271- } \\
10-3-5\end{array}$ & Exp. & Pioneer-2684/FFR 522//IN 92201 & Univ. Georgia & SRW & 2007-08 ESN & 5.2 & 5.2 \\
\hline Jagger & PI 593688 & KS-82-W-418/Stephens & Oklahoma State & HRW & 2010-11 ESN & 6.3 & 3.5 \\
\hline LA 03217 E2 & Exp. & RO23/Pioneer-26R61 & LSU & SRW & 2010-11 ESN & 6.8 & 3.8 \\
\hline LA 03217D-P2 & Exp. & RO23/Pioneer-26R61 & LSU & SRW & 2010-11 ESN & 7.3 & 4.3 \\
\hline LA 04041D-10 & Exp. & AGS 2060/GA951079A25 & LSU & SRW & 2010-11 ESN & 7.8 & 4.3 \\
\hline Magnolia & PI 648024 & Elekhart/Mason & $\begin{array}{l}\text { Syngenta } \\
\text { (AgriPro) }\end{array}$ & SRW & 2009-10 NCOVT & \multicolumn{2}{|l|}{ Susceptible } \\
\hline $\begin{array}{l}\text { MD00W16- } \\
07-3\end{array}$ & Exp. & $\begin{array}{l}\text { Doubled-haploid selection from } \\
\text { USG3209/WXE871093A }\end{array}$ & Univ. Maryland & SRW & 2007-08 ESN & 6.2 & 5.5 \\
\hline NC-Neuse & PI 633037 & Coker-86-29//Stella/CHD-756-80/3/Coker-9907 & NCSU & SRW & 2010-11 ESN & 3.8 & 1.3 \\
\hline Parula & PI 520340 & $\begin{array}{l}\text { Frontana/Kenya-58//Newthatch/3/2*Frocor// } \\
\text { Kenya-AD/GABO-54/4/Bluebird/Chanate }\end{array}$ & CIMMYT & HWS & 2011-12 SELRN & 9.0 & 9.0 \\
\hline $\begin{array}{l}\text { Pavon } 753 \\
(\operatorname{Lr} 47)\end{array}$ & PI 603918 & Pavon T7AS-7S\#1S-7AS-7AL & CIMMYT & HRS & 2011-12 SELRN & 9.0 & 9.0 \\
\hline Pavon 76 & PI 519847 & $\begin{array}{l}\text { Vican-71//Ciano-67/Siete-Cerros-66/3/ } \\
\text { Kalyansona/Bluebird }\end{array}$ & CIMMYT & HRS & 2011-12 SELRN & 9.0 & 9.0 \\
\hline Pembroke & Exp. & VA 94-52-25/KY87C-42-8-5//Pioneer-2552 & Univ. Kentucky & SRW & 2010-11 ESN & 6.3 & 3.5 \\
\hline $\begin{array}{r}\text { PI520360 } \\
\text { (CSP44) }\end{array}$ & PI 520360 & Selection from Condor & Australia & HRW & 2011-12 SELRN & 9.0 & 9.0 \\
\hline Provinciale & None & Baroudeur/Genesis & Serasem, France & SRW & Not tested & -- & -- \\
\hline Récital & PI 573733 & Mexique-267(R-267)/9369 & Benoist, France & HWW & Not tested & -- & -- \\
\hline Siouxland & PI 483469 & CO-68-F-6635*2/Kavkaz & Univ. Nebraska & HRW & Not tested & -- & -- \\
\hline T177 & Exp. & Pur92145E8-7-7-1-9/B116 & Trio Research, KS & SRW & 2010-11 ESN & 8.0 & 6.5 \\
\hline T178 & Exp. & Pur92145E8-7-7-1-9/B116 & Trio Research, KS & SRW & 2010-11 ESN & 8.5 & 7.5 \\
\hline TAM 303 & Exp. & $\begin{array}{l}\text { TX89D1253*2/TTCC404 (=WX93D208-9-1-2) } \\
(=\text { TX98D1170) }\end{array}$ & Texas A \& M & HRW & 2011-12 ESN & 7.0 & 5.0 \\
\hline Trego & PI 612576 & KS-87-H-325/Rio-Blanco & Kansas State & HWW & Not tested & -- & -- \\
\hline WGRC36 & PI 604221 & $\begin{array}{l}\text { TAM-107*4/(TR.TI)TA- } 870 \\
\text { Wrangler*3/(TR.TI)TA-145 }\end{array}$ & Kansas State & HRW & Not tested & Susceptible & \\
\hline \multicolumn{8}{|c|}{ Controls with known sensitivities } \\
\hline $\begin{array}{l}\text { Grandin }(\mathrm{Tsn} 1, \\
\text { Snn2, Snn3) }\end{array}$ & PI 531005 & Lenana//Butte*2/ND-507/3/ND-593 & NDSU & HRS & Not tested & -- & -- \\
\hline BG261 (Tsn1) & RIL & Grandin/BR34 & NDSU & HRS & Not tested & -- & -- \\
\hline $\begin{array}{l}\text { Chinese Spring } \\
\text { (Snn1) }\end{array}$ & CItr 14108 & Introduction (=Chinese White) & N/A & HWS & Not tested & -- & -- \\
\hline BG223 (Snn2) & RIL & Grandin/BR34 & NDSU & HRS & Not tested & -- & -- \\
\hline BG220 (Snn3) & RIL & Grandin/BR34 & NDSU & HRS & Not tested & -- & -- \\
\hline $\mathrm{Br} 34$ (none) & None & Alvarez-110/2*IAS-54//F-5530 & $\begin{array}{l}\text { EMBRAPA, } \\
\text { Brazil }\end{array}$ & HRS & Not tested & -- & -- \\
\hline
\end{tabular}

\footnotetext{
${ }^{a}$ Among the 26 cultivars with unknown NE sensitivities, NC Neuse was moderately resistant to SNB in the field; all others were known or hypothesized to be susceptible. For controls, necrotrophic effector sensitivities are in parentheses.

${ }^{\mathrm{b}} \mathrm{CI}=$ Cultivar Introduction, Exp. $=$ experimental, $\mathrm{PI}=$ Plant Introduction, $\mathrm{RIL}=$ recombinant inbred line .

${ }^{\mathrm{c}}$ HRS $=$ hard red spring, HRW = hard red winter, HWS = hard white spring, HWW = hard white winter, SRW = soft red winter, S/H RW = intermediately hard red winter.

${ }^{\mathrm{d}}$ ESN = Eastern Septoria Nursery; NCOVT = North Carolina Official Variety Trial; SELRN $=$ Southeast Leaf Rust Nursery.

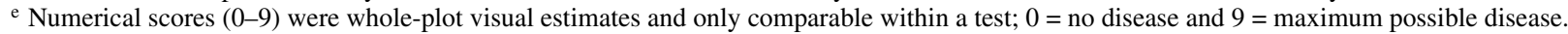




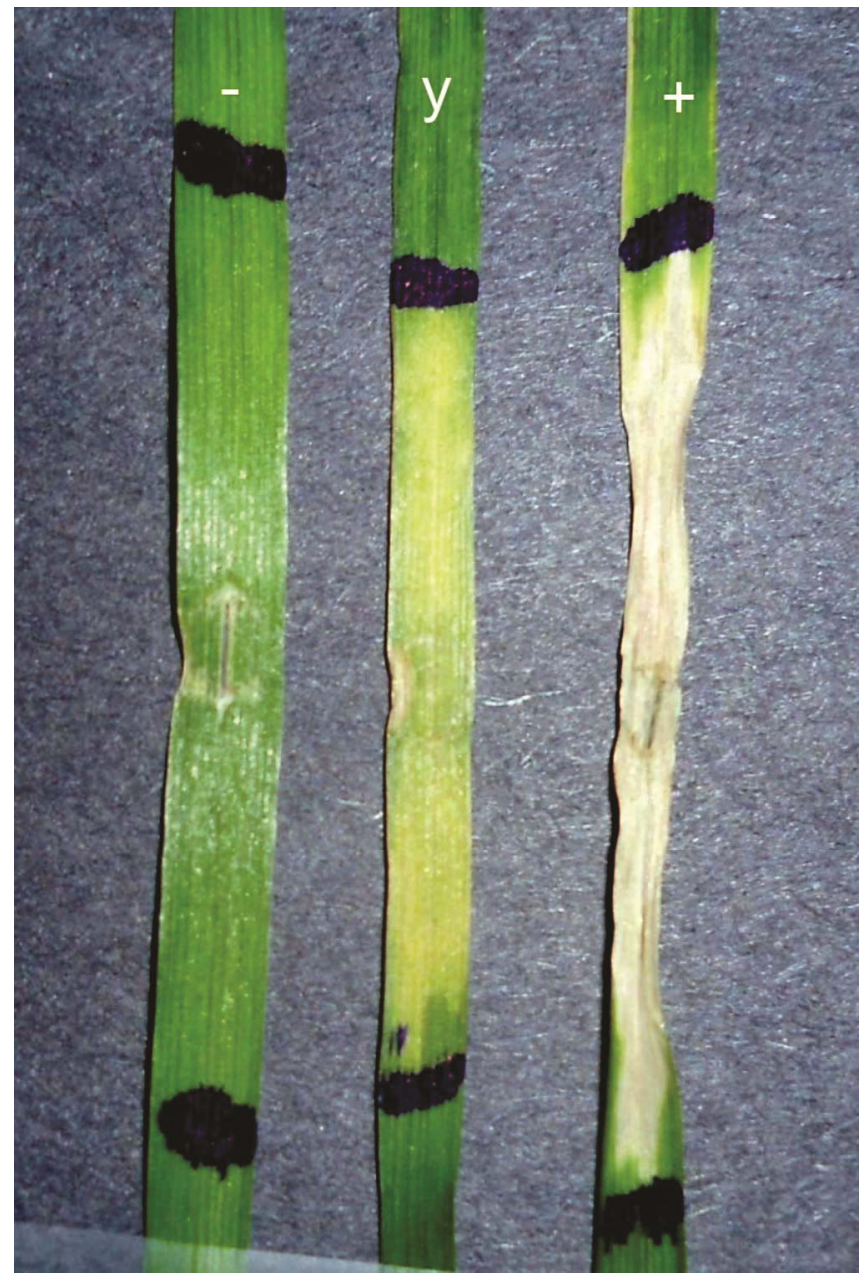

Fig. 1. Rating scale for sensitivity to necrotrophic effectors produced by Stagonospora nodorum isolates in liquid culture and infiltrated into leaves of 14- to 17day-old wheat seedlings. Sensitivity was evaluated 7 days post infiltration and recorded as the majority phenotype of three replicate plants per trial. Insensitive (-), chlorotic $(y)$, necrotic $(+)$. temperatures was adjusted for optimization of each marker. One of each pair of primers was $5^{\prime}$ labeled with IR 700 or IR 800 fluorescent labels. The fluorescent-labeled PCR product was visualized on 6\% polyacrylamide gel using a LI-COR 4200 gel imager (LI-COR Biotechnology). GeneProfiler 4.05 (Scanalytics Inc.) was used to score the digital images of the polyacrylamide gels.

\section{Results}

NE sensitivity of cultivars. Sensitivity genes in the experimental wheat cultivars were detected by infiltration with CFs produced by the P. pastoris yeast strains. The infiltration assay showed that eight $(31 \%)$ of the tested cultivars exhibited a sensitive response $(\mathrm{y}$ or + ) to SnToxA produced by $P$. pastoris; these cultivars were therefore determined to contain the Tsnl sensitivity gene (Table 3). As expected, the Tsn1 controls Grandin and BG-261 were sensitive to SnToxA in CFs produced by P. pastoris.

None of the experimental cultivars was sensitive to SnTox1 in CFs produced by P. pastoris (Table 3 ). The Snn1 control, Chinese Spring, did show the expected sensitivity to SnTox1, indicating that Snnl was otherwise not present in this cultivar collection.

Sixteen $(62 \%)$ of the cultivars were sensitive to SnTox 3 in $P$. pastoris CFs (Table 3 ) and, therefore, contained the $S n n 3$ sensitivity gene. Grandin and BG-220, both known to possess Snn3, were sensitive as well. Five of the cultivars (19\%) were sensitive to both SnToxA and SnTox3 in CFs produced by $P$. pastoris, indicating that the cultivars harbored both Tsn1 and Snn3.

The cultivars varied greatly in the number of southeastern $S$. nodorum isolates to which they exhibited sensitive responses, ranging from 0 to 19 isolates (58\%; Table 4). In all, 19 (73\%) of the cultivars were sensitive to NEs from at least one of the southeastern $S$. nodorum isolates and 24 (92\%) were sensitive to NEs from at least one of the $S$. nodorum control isolates from North Dakota (Table 4). Twenty-five (96\%) of the cultivars were sensitive to NEs produced by either $S$. nodorum isolates or P. pastoris controls. Only the moderately SNB-resistant NC-Neuse was insensitive to all NEs produced in the trials. Seven $(27 \%)$ cultivars were sensitive to NEs from southeastern isolates that elicited no sensitive responses among control cultivars (Table 3).

A majority of the sensitive responses to southeastern SNB isolates were observed in SnTox3-sensitive cultivars and were likely due to the SnTox3-Snn3 interaction (Table 3). Among SnTox3-

Table 2. Molecular markers evaluated for utility in detecting wheat genes conferring sensitivity to necrotrophic effectors produced by Stagonospora nodorum

\begin{tabular}{|c|c|c|c|c|c|c|c|}
\hline Marker & Type $^{\mathbf{a}}$ & Gene & Primer sequence & $\begin{array}{l}\text { Product size } \\
\text { (bp) })^{\mathbf{b}}\end{array}$ & $\begin{array}{l}\text { Distance } \\
\text { from gene }^{\mathrm{c}}\end{array}$ & $\begin{array}{l}\text { Chr. } \\
\text { arm }^{\text {d }}\end{array}$ & Reference $^{\mathrm{e}}$ \\
\hline \multirow[t]{2}{*}{ Xfcp394 } & SSR & $T s n 1$ & 5' GTAGCCTGCAGGTACAAACTGGA 3' & $328-T s n 1$ & & & \\
\hline & & & 5' CAGTGTTAAGAAGTGTGTTCTGGTC $3^{\prime}$ & $383-t s n 1$ & $0.5 \mathrm{cM}$ distal & $5 \mathrm{BL}$ & 34 \\
\hline \multirow{2}{*}{ Xfсp620 } & SSR & Tsn1 & 5' CATAACCTTCATACGGACTTGCTCAC 3' & $252-T s n 1$ & & & \\
\hline & & & 5' TATTCTTGCCAGTGTTGGGAGGG 3' & 226-tsn1 & N/A & $5 \mathrm{BL}$ & 34 \\
\hline \multirow[t]{2}{*}{ Xfcp623 } & SSR & Tsn1 & 5' CTATTCGTAATCGTGCCTTCCG 3' & & & & \\
\hline & & & 5' ССТTCТCTCTCACCGCTATCTCATC $3^{\prime}$ & $380-T s n 1$ & Internal to gene & $5 \mathrm{BL}$ & 9 \\
\hline \multirow[t]{2}{*}{$X f c p 624$} & SSR & Snnl & 5' GTGCTGCTAAATGGATTCCTAAGC 3' & & & & \\
\hline & & & 5' CCAAACTGGCAAAAGATTGAGC 3v & 345-Snn1 & N/A & 1BS & $\mathrm{JF}$ \\
\hline \multirow[t]{2}{*}{ Xpsp3000 } & SSR & Snn1 & 5' GCAGACCTGTGTCATTGGTC 3' & 281-Snn1 & & & \\
\hline & & & 5' GATATAGTGGCAGCAGGATACG 3' & $252-$ snn 1 & $0.4 \mathrm{cM}$ proximal & 1BS & 25 \\
\hline \multirow[t]{2}{*}{$X c f d 51$} & SSR & Snn2 & 5' GGAGGCTTCTCTATGGGAGG 3' & & & & \\
\hline & & & 5' TGCATCTTATCCTGTGCAGC $3^{\prime}$ & $153+182-$ Snn 2 & $0.4 \mathrm{cM}$ proximal & 2DS & 34 \\
\hline \multirow[t]{2}{*}{$X c f d 56$} & SSR & Snn2 & 5' TTGCATAATTACTTGCCCTCC $3^{\prime}$ & & & & \\
\hline & & & 5' CTGGTCCAACTTCCATCCAT 3' & Not reported & $7.7 \mathrm{cM}$ distal & 2DS & 34 \\
\hline \multirow[t]{2}{*}{ XTC253803 } & EST & Snn2 & $5^{\prime}$ TGCTTTTGTGCCAGATGATG $3^{\prime}$ & & & & \\
\hline & & & 5' CCACCGGGACAAGTCAGATA 3' & 196, 197-Snn2 & $3.6 \mathrm{cM}$ distal & 2DS & 34 \\
\hline \multirow[t]{2}{*}{$X c f d 20$} & SSR & Snn3-5B & $5^{\prime}$ TGATGGGAAGGTAATGGGAG 3' & & & & \\
\hline & & & 5' ATCCAGTTCTCGTCCAAAGC 3' & Not reported & $1.4 \mathrm{cM}$ proximal & 5BS & 17 \\
\hline \multirow[t]{2}{*}{ Xgwm234 } & SSR & Snn3-5B & 5' GAGTCCTGATGTGAAGCTGTTG 3' & & & & \\
\hline & & & 5' CTCATTGGGGTGTGTACGTG 3' & 244-Snn3 & N/A & 5BS & $26, \mathrm{JF}$ \\
\hline
\end{tabular}

a Simple sequence repeat (SSR) or expressed-sequence tag (EST).

${ }^{\mathrm{b}}$ Predicted product size based on publication or Grain Genes database, and corresponding allele where available in publication.

${ }^{\mathrm{c}}$ Distance in centimorgans $(\mathrm{cM})$ of marker from the gene of interest. N/A = not available.

d Wheat chromosome arm.

e JF = Justin Faris, personal communication. 
sensitive cultivars, the number of southeastern isolates eliciting a sensitive response ranged from 9 (AGS 2000) to 19 (ARS05-0242), or 27 to $58 \%$ of isolates (Table 3). Among the SnTox3-insensitive cultivars, up to four but most commonly zero southeastern isolates elicited a sensitive response.

Insensitivity to SnToxA, SnTox1, and SnTox 3 was displayed by four SNB-susceptible cultivars (Table 3). Of these, ARS 12-532 was sensitive to four southeastern isolates, 'GA 001271-10-3-5' was sensitive to NC8-6 and Sn6, and Pembroke was sensitive only to Sn6. Sensitivity in these three cultivars was also not due to Snn2, because they lacked sensitivity to $\mathrm{Sn} 4$. The fourth cultivar, 'MD00W16-07-3', was sensitive to both Sn4 and Sn6; thus, it might possess Snn2. Like GA 001271-10-3-5 and Pembroke, 'Provinciale' and 'Récital' were sensitive only to Sn6 NEs. However, the latter two cultivars' field response to SNB is unknown at this time; they were included in the study because they appeared in the pedigree of susceptible cultivars.

NE production of $\boldsymbol{S}$. nodorum isolates. CFs from 20 (61\%) of the southeastern U.S. S. nodorum isolates included in this study contained NEs that caused a sensitive response in at least one of the tested wheat cultivars (Table 3). The remaining southeastern isolates either produced no NEs in culture or none that were recognized by the wheat cultivars represented in the trials.

The Snnl differential wheat Chinese Spring showed no sensitivity to NEs of any of the 33 experimental isolates but was sensitive to SnTox 1 in CFs of the P. pastoris yeast control (Table 3). Sn2000 was previously reported to produce $\operatorname{SnTox} 1(18,23)$ but trials of the present experiment involving Sn2000 CFs and Chinese Spring were unsuccessful and those data are not available (Table 3 ). The Snn2 differential wheat BG-223 showed no sensitivity to the NEs of any of the 33 experimental isolates. BG-223 was sensitive to Sn4 and Sn6 (Table 3), both known to produce SnTox2 $(15,19)$.

The Snn 3 controls Grandin and BG-220 were sensitive to NEs of $14(42 \%)$ and $12(36 \%)$ isolates, respectively. This suggested that at least 12 of the southeastern S. nodorum isolates were SnTox3 producers. The previously conducted dot-blot assay showed that 15 (46\%) of these isolates contained the SnTox3 gene (7). Thus, three southeastern isolates contained the SnTox3 gene but did not produce SnTox3 in culture.

North Dakota isolates Sn4 and Sn6, both known to produce SnTox3 $(15,19)$, elicited the expected sensitive response in Snn3 controls Grandin and BG-220 (Table 3). Among the SnTox3-sensitive cultivars, $14(88 \%)$ and $16(100 \%)$ were sensitive to NEs of Sn4 and Sn6, respectively (Table 3). AGS2000, which showed a chlorotic rather than a necrotic response to SnTox3 from the $P$. pastoris strain, was the only SnTox3-sensitive cultivar that was insensitive to NEs of Sn4. The SnTox3-Snn3 interaction can cause reactions ranging from mild chlorosis to necrosis (33), which may explain the apparent insensitivity of AGS2000 to NEs of Sn4.

Grandin is known to possess Tsn1 (16), Snn2 (15), and Snn3 (17). A sensitive response in Grandin could be the result of one or all sensitivity genes. Both the Tsn1 and Snn2 differentials (BG-261 and BG-223, respectively) were insensitive to NEs from all southeastern isolates (Table 3 ). This suggests that the sensitive reactions

Table 3. Response of wheat seedling leaves in infiltration assay to culture filtrates of Stagonospora nodorum isolates or Pichia pastoris yeast strains engineered to produce specific necrotrophic effectors $(\mathrm{NEs})^{\mathrm{a}}$

\begin{tabular}{|c|c|c|c|c|c|c|c|c|c|c|c|c|c|c|c|c|c|c|c|c|c|c|c|c|c|c|c|c|c|c|c|c|c|c|c|c|c|c|c|c|}
\hline & \multirow[b]{2}{*}{$\begin{array}{l}\text { Wheat } \\
\text { cultivar }^{\text {b }}\end{array}$} & \multicolumn{33}{|c|}{ Southeastern isolates of $S$. nodorum ${ }^{\mathrm{c}}$} & \multicolumn{3}{|c|}{$\begin{array}{l}\text { Control } \\
\text { isolates }\end{array}$} & \multicolumn{3}{|c|}{$\underset{\text { pastoris }}{\text { Pichia }}$} \\
\hline & & $\frac{\vec{\pi}}{\dot{1}}$ & 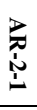 & $\underset{t}{t}$ & $\begin{array}{l}0 \\
\stackrel{1}{0} \\
\stackrel{1}{0}\end{array}$ & مُ & $\begin{array}{l}Z \\
\mathfrak{1} \\
1\end{array}$ & $\begin{array}{l}Z \\
2 \\
\infty \\
\dot{b}\end{array}$ & $\begin{array}{l}Z \\
2 \\
\infty \\
\infty \\
\infty\end{array}$ & 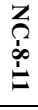 & $\begin{array}{l}z \\
\text { b } \\
\text { ú }\end{array}$ & 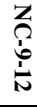 & 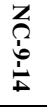 & 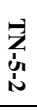 & خ & 永 & $\stackrel{b}{b}$ & $\begin{array}{l}2 \\
b \\
b\end{array}$ & $\begin{array}{l}z \\
\stackrel{b}{u} \\
\dot{n}\end{array}$ & $\begin{array}{l}Z \\
Z \\
\dot{d} \\
\dot{\omega}\end{array}$ & \begin{tabular}{l}
3 \\
\multirow{1}{*}{+} \\
+
\end{tabular} & $\stackrel{\mathscr{2}}{\dot{L}}$ & $\begin{array}{l}\text { 竞 } \\
\dot{u} \\
\stackrel{1}{-}\end{array}$ & מُ & $\begin{array}{l}\text { 竞 } \\
\text { ún } \\
\text { ún }\end{array}$ & 总 & 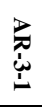 & 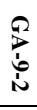 & 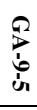 & $\begin{array}{l}Z \\
2 \\
0 \\
0\end{array}$ & $\stackrel{\mathscr{L}}{\stackrel{\mathscr{L}}{1}}$ & $\stackrel{\mathscr{L}}{\dot{N}}$ & 峁 & d & $\mathscr{E}$ & $\mathscr{\Xi}$ & 怘 & $\overrightarrow{8}$ & $\overrightarrow{0}$ & $\overrightarrow{\mathrm{e}}$ \\
\hline \multirow{26}{*}{ 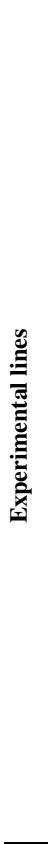 } & ARS 12-532 & - & - & - & - & - & - & - & - & - & - & - & - & - & - & - & - & - & - & - & - & $\mathrm{y}$ & + & - & - & - & o & o & - & - & + & + & - & - & t & - & o & - & - & - \\
\hline & Neuse & - & - & - & - & - & - & - & - & - & - & - & - & . & - & - & - & - & - & - & - & - & - & - & - & - & o & o & - & - & - & - & - & - & - & - & - & - & - & - \\
\hline & Jagger & - & - & - & - & - & - & - & - & - & - & - & - & - & - & - & - & - & - & - & - & - & - & - & - & - & - & - & - & - & - & - & - & - & - & - & + & + & - & - \\
\hline & $\begin{array}{r}\text { PI520360 } \\
\text { (CSP44) }\end{array}$ & - & - & - & - & - & - & - & - & - & - & - & - & - & - & - & - & - & - & - & - & - & - & - & - & - & - & - & - & - & - & - & - & - & - & - & + & + & - & - \\
\hline & Siouxland & - & - & - & - & - & - & - & - & - & - & - & - & 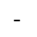 & - & - & - & - & - & - & - & - & - & - & - & - & - & - & - & - & - & - & - & - & - & - & - & + & - & - \\
\hline & $\begin{array}{l}\text { GA 001271- } \\
10-3-5\end{array}$ & - & - & - & - & - & o & o & - & - & - & o & - & - & - & - & - & - & - & - & o & - & o & - & - & - & - & - & - & $\mathrm{y}$ & - & - & - & - & o & $\mathrm{y}$ & - & - & - & - \\
\hline & Pembroke & - & - & - & - & - & - & - & - & - & - & - & - & - & - & - & - & - & - & - & - & - & - & - & - & - & - & - & - & - & - & - & - & - & - & $\mathrm{y}$ & - & - & - & - \\
\hline & Provinciale & - & - & - & - & - & - & - & - & - & - & - & - & - & - & - & - & - & - & - & - & - & - & - & - & - & - & - & - & - & - & - & - & - & - & $\mathrm{y}$ & - & - & - & - \\
\hline & Recital & - & - & - & - & - & - & - & - & - & - & - & - & - & - & - & - & - & - & - & - & - & - & - & - & - & - & - & - & - & - & - & - & - & - & $\mathrm{y}$ & - & - & - & - \\
\hline & $\begin{array}{l}\text { MD00W16- } \\
07-3\end{array}$ & - & - & - & - & - & - & - & - & - & - & - & - & - & - & - & - & - & - & - & - & - & - & - & - & - & - & - & - & + & - & - & - & - & + & + & - & - & - & - \\
\hline & Parula & - & - & - & - & - & - & - & - & - & - & - & - & - & - & - & - & - & - & - & - & - & - & - & $\mathrm{y}$ & $\mathrm{y}$ & $\mathrm{y}$ & + & $\mathrm{y}$ & + & $\mathrm{y}$ & $\mathrm{y}$ & $\mathrm{y}$ & $\mathrm{y}$ & g & $\mathrm{y}$ & . & - & - & $\mathrm{y}$ \\
\hline & AGS 2000 & - & - & - & - & - & - & - & - & - & - & - & - & - & - & - & - & - & - & - & - & - & - & - & 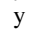 & - & $\mathrm{y}$ & $\mathrm{y}$ & $\mathrm{y}$ & $\mathrm{y}$ & + & $\mathrm{y}$ & $\mathrm{y}$ & $\mathrm{y}$ & - & + & - & - & - & $\mathrm{y}$ \\
\hline & LA 04041D-10 & - & - & - & - & - & - & - & - & - & - & - & - & - & - & - & - & - & - & $\mathrm{y}$ & $\mathrm{y}$ & $\mathrm{y}$ & $\mathrm{y}$ & $\mathrm{y}$ & + & $\mathrm{y}$ & + & + & $\mathrm{y}$ & + & + & $\mathrm{y}$ & $\mathrm{y}$ & $\mathrm{y}$ & + & $\mathrm{y}$ & - & - & - & + \\
\hline & ARS & - & - & - & - & - & - & - & - & - & - & - & - & - & - & - & - & - & - & - & $\mathrm{y}$ & - & $\mathrm{y}$ & $\mathrm{y}$ & $\mathrm{y}$ & $\mathrm{y}$ & o & o & + & I & + & - & $\mathrm{y}$ & - & I & + & o & - & - & + \\
\hline & ARSO & - & $\mathrm{y}$ & $\mathrm{y}$ & - & - & - & - & - & - & - & - & - & - & - & $\mathrm{y}$ & - & $\mathrm{y}$ & - & + & + & + & + & + & + & + & + & + & + & + & + & + & + & + & + & + & + & - & - & + \\
\hline & LA 03217 E2 & - & - & - & - & - & - & - & - & - & - & - & - & - & - & - & - & - & - & - & - & $\mathrm{y}$ & + & $\mathrm{y}$ & + & + & + & + & + & + & + & + & + & + & + & + & - & - & - & + \\
\hline & LA 03217D-P2 & - & - & - & - & - & - & - & - & - & - & - & - & - & - & - & - & - & - & - & - & $\mathrm{y}$ & + & $\mathrm{y}$ & + & + & + & + & + & + & + & + & + & + & + & + & - & - & - & + \\
\hline & Magnolia & - & - & - & - & - & - & - & - & - & - & - & - & - & - & - & - & - & - & - & - & $\mathrm{y}$ & + & + & + & + & + & + & + & + & + & + & + & + & + & + & - & - & - & + \\
\hline & $\mathrm{T} 177$ & - & - & - & - & - & - & - & - & - & - & - & - & - & - & - & - & - & - & $\mathrm{y}$ & + & $\mathrm{y}$ & $\mathrm{y}$ & $\mathrm{y}$ & + & + & + & + & + & + & + & + & + & + & + & + & $\mathrm{y}$ & - & - & + \\
\hline & $\mathrm{T} 178$ & - & - & - & - & - & - & - & - & - & - & - & - & - & - & - & - & - & - & $\mathrm{y}$ & $\mathrm{y}$ & $\mathrm{y}$ & $\mathrm{y}$ & $\mathrm{y}$ & + & + & + & + & + & + & + & $\mathrm{y}$ & + & $\mathrm{y}$ & + & + & $\mathrm{y}$ & - & - & + \\
\hline & Trego & - & - & - & - & - & - & - & - & - & - & - & - & - & - & - & - & - & - & - & $\mathrm{y}$ & $\mathrm{y}$ & $\mathrm{y}$ & $\mathrm{y}$ & + & + & + & + & + & + & + & + & + & + & + & + & - & - & - & + \\
\hline & ARS $12-53$ & - & - & - & - & - & - & - & - & - & - & - & - & - & - & - & - & - & - & - & $\mathrm{y}$ & $\mathrm{y}$ & $\mathrm{y}$ & $\mathrm{y}$ & $\mathrm{y}$ & $\mathrm{y}$ & o & o & + & + & + & $\mathrm{y}$ & $\mathrm{y}$ & + & + & + & o & + & - & + \\
\hline & $\begin{array}{l}\text { Pavon } 753 \\
\text { (Lr47) }\end{array}$ & - & - & - & - & - & - & - & - & - & - & - & - & - & - & - & - & - & - & - & - & $\mathrm{y}$ & $\mathrm{y}$ & $\mathrm{y}$ & + & + & + & + & + & + & + & $\mathrm{y}$ & + & + & + & + & + & + & - & + \\
\hline & Pavon 76 & - & $\mathrm{y}$ & - & - & - & - & - & - & - & - & - & - & 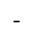 & 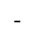 & - & - & - & - & - & - & $\mathrm{y}$ & $\mathrm{y}$ & $\mathrm{y}$ & + & + & + & + & + & + & + & + & + & + & + & + & $\mathrm{y}$ & + & - & + \\
\hline & TAM 303 & - & $\mathrm{y}$ & - & - & - & - & - & - & - & - & - & - & - & - & - & - & - & - & + & + & $\mathrm{y}$ & $\mathrm{y}$ & $y$ & + & + & + & + & + & + & + & + & + & + & + & + & + & + & - & + \\
\hline & WGRC36 & - & - & - & - & - & - & - & - & - & - & - & - & - & - & - & - & $\mathrm{y}$ & $\mathrm{y}$ & + & + & + & $\mathrm{y}$ & + & + & + & + & + & + & + & + & + & + & + & + & + & + & + & - & + \\
\hline \multirow{6}{*}{ 节 } & Grandin & - & - & - & - & - & - & - & - & - & - & - & - & 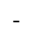 & 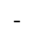 & - & - & - & - & - & J & J & $\mathrm{y}$ & $\mathrm{y}$ & J & + & + & + & + & + & + & + & + & + & r & + & $\mathrm{y}$ & + & - & + \\
\hline & BG-261 & - & - & - & - & - & - & - & - & - & - & - & - & - & - & - & - & - & - & - & - & - & - & - & - & - & - & - & - & - & - & - & - & - & - & - & + & + & - & - \\
\hline & $\begin{array}{r}\text { Chinese } \\
\text { Spring }\end{array}$ & - & - & - & - & - & - & - & - & - & - & - & - & - & - & - & - & - & - & - & - & - & - & - & - & - & o & o & - & - & - & - & - & - & - & - & o & - & $\mathrm{y}$ & - \\
\hline & BG-223 & - & - & - & - & - & - & - & - & - & - & - & - & - & - & - & - & - & - & - & - & - & - & - & - & - & - & - & - & - & - & - & - & - & + & $\mathrm{y}$ & - & - & - & - \\
\hline & BG-220 & - & - & - & - & - & - & - & - & - & - & - & - & - & - & - & - & - & - & - & - & - & $\mathrm{y}$ & $\mathrm{y}$ & + & $\mathrm{y}$ & + & + & + & + & + & + & + & + & $\mathrm{y}$ & + & - & - & - & + \\
\hline & Br34 & - & - & - & - & - & - & - & - & - & - & - & - & - & - & - & - & - & - & - & - & - & - & - & - & - & - & - & - & - & - & - & - & - & - & - & - & - & - & - \\
\hline
\end{tabular}

${ }^{a}$ Responses were scored as negative (-), chlorotic (y), or necrotic (+) at 7 days post-infiltration; " " = disagreement among replications; "o" = missing data.

b For control cultivars, known sensitivity genes indicated in parentheses.

c Isolates named for state of origin.

d Control isolates from North Dakota with known NE production.

e $P$. pastoris yeast strains engineered to produce NEs in culture. 
of Grandin were due to either the Snn3-SnTox3 interaction or novel NE-sensitivity gene interactions.

Six (18\%) southeastern isolates produced NEs that elicited sensitivity in the experimental cultivars but caused no sensitivity in the control cultivars (Table 3). It is possible that these sensitive responses were due to the Snn4-SnTox4 interaction (1), the Snn5SnTox5 interaction (13), or unreported sensitivity genes and NEs. The experimental 'LA04041D10' was sensitive to NEs produced by isolates NC 8-3 and TN 5-1 but insensitive to NEs from Sn2000, which is known to produce SnTox5 (13). This suggests that the sensitivity in the Louisiana experimental line caused by the two southeastern isolates was not due to SnTox5.

Marker data. The Xfcp623 marker amplified the 380-bp fragment associated with Tsnl in eight of the experimental wheat cultivars and also in the two controls, BG-261 and Grandin, which are known to possess Tsnl (Table 2; Fig. 2). The eight experimental lines were also all sensitive to SnToxA produced in CFs of $P$. pastoris, confirming the utility of $X f c p 623$ as a diagnostic marker in germplasm relevant to southeastern wheat breeding programs (9). For the other markers tested, there was no association between amplicons produced and presence of the respective sensitivity genes. When compared with the CF infiltration assay, the amplified fragments showed either nondiagnostic polymorphism or no polymorphism between sensitive and insensitive lines (data not shown).

\section{Discussion}

To our knowledge, this study is the first to investigate which sensitivity genes contribute to SNB susceptibility among a selection of susceptible wheat cultivars in North America. A previous study by Crook et al. (7) showed that sensitivity to NEs was more common in SNB-susceptible cultivars than in resistant cultivars from the southeastern United States. The present study follows up by providing the first insight into the sensitivity genes that are contributing to SNB susceptibility in this geographic region. Evaluation of reported molecular markers for host sensitivity genes was conducted systematically to determine whether the markers could be employed in MAS in the region; although most were found not to be diagnostic, one marker was confirmed to be useful in detecting Tsn1 in a collection of southeastern U.S. germplasm.

The present set of SNB-susceptible cultivars consisted of 58\% soft red winter wheat lines (commercial varieties or advanced experimental lines) adapted to the southeastern United States and $42 \%$ hard wheat lines from the U.S. Great Plains, Australia, or CIMMYT used to introgress traits, including hardness and rust resistance. These two groups of lines were drawn from adapted germplasm and also from new germplasm being introduced to the southeastern United States. Infiltration results indicate that Tsn1 and Snn 3 were present in 31 and $62 \%$ of the wheat lines, respectively, and $20 \%$ contained both Tsn 1 and Snn3.

Two reported NEs, SnTox1 and SnTox2, were not detected in the CFs of any southeastern U.S. S. nodorum isolates. Chinese Spring and BG-223, the Snn1 and Snn2 controls, were insensitive to NEs from all southeastern U.S. isolates. This suggests that these isolates do not produce SnTox1 or SnTox2 in culture, at least in a form that is recognizable by wheat lines containing $S n n 1$ or $S n n 2$. A previous dot-blot assay determined that $74 \%$ of the larger sample of 39 southeastern U.S. S. nodorum isolates carried the SnTox1 gene (7); therefore, it is possible that culturing conditions were not conducive to SnTox 1 production. Alternatively, the southeastern isolates may carry nonfunctioning SnToxl alleles, similar to nonfunctional SnToxA alleles that have been reported (30). The existence of nonfunctional haplotypes could also explain the discrepancy between the $15(46 \%)$ southeastern U.S. isolates containing the SnTox3 gene (7) and $12(36 \%)$ isolates that actually produced SnTox 3 in culture. Sequence analysis of each isolate would be necessary to determine whether this is the case.

Seven cultivars were sensitive to NEs produced by southeastern U.S. S. nodorum isolates that elicited no sensitivity in the control cultivars. These sensitive responses were potentially the result of novel sensitivity genes but it is also possible that sensitivity was conferred by Snn4 (1) or Snn5 (13), which we were unable to detect.

Reactions to NEs produced in culture were not always identical among sensitive cultivars. For example, AGS2000 and 'Parula' each exhibited a chlorotic reaction when infiltrated with SnTox3 produced by $P$. pastoris but all other SnTox3-sensitive cultivars had a necrotic reaction (Table 3). Interestingly, AGS2000 and Parula were each insensitive to NEs of three southeastern U.S. S. nodorum isolates that were SnTox3 producers (Table 3). The SnTox3-Snn3 interaction varies in severity of the sensitive response (33), potentially as a result of multiple genes that confer sensitivity to SnTox3 (35). The sensitive reactions of these two cultivars may have been due to sensitivity genes other than $S n n 3-5 B$, the sensitivity gene of Snn3 differentials Grandin and BG-220 in this study. It is possible that AGS2000 and Parula possess Snn3-5D (35) or a novel gene for sensitivity to SnTox3. It is also possible that SnTox3 has multiple isoforms that elicit varying levels of sensitivity, as is the case with SnToxA (31).

Although Tsn1 and Snn3 appeared with high frequency in the selected SNB-susceptible wheat cultivars, it should be noted that $24 \%$ of the studied cultivars were insensitive to both SnToxA and SnTox3. In most cases, these SnToxA- and SnTox3-insensitive cultivars were sensitive to NEs from the North Dakota isolate Sn6. Among those in this category that are adapted to the southeastern United States were GA001271-10-3-5, MD00W16-07-3, and Pembroke. Other factors apparently influence disease development in these cultivars; for example, it is possible that uncharacterized pairs of sensitivity genes and NEs are playing a role. It is also possible that traits apart from this inverse gene-for-gene dynamic are

Table 4. Number of Stagonospora nodorum isolates and Pichia pastoris yeast strains producing sensitive responses in infiltration assay of wheat seedling leaves

\begin{tabular}{|c|c|c|c|}
\hline \multirow[b]{3}{*}{ Wheat cultivar } & \multicolumn{3}{|c|}{ Number of isolates eliciting sensitivity ${ }^{a}$} \\
\hline & \multicolumn{3}{|c|}{ S. nodorum ${ }^{\mathrm{b}}$} \\
\hline & Southeast & Controls & + P. pastoris ${ }^{\mathrm{c}}$ \\
\hline NC-Neuse & 0 & 0 & 0 \\
\hline Siouxland & 0 & 0 & 1 \\
\hline Pembroke & 0 & 1 & 1 \\
\hline Provinciale & 0 & 1 & 1 \\
\hline Recital & 0 & 1 & 1 \\
\hline Jagger & 0 & 1 & 2 \\
\hline PI520360 (CSP44) & 0 & 1 & 2 \\
\hline GA 001271-10-3-5 & 1 & 1 & 2 \\
\hline MD00W16-07-3 & 1 & 2 & 3 \\
\hline ARS 12-532 & 4 & 1 & 5 \\
\hline AGS 2000 & 9 & 1 & 11 \\
\hline ARS $12-533$ & 9 & 2 & 12 \\
\hline Parula & 10 & 2 & 13 \\
\hline ARS 12-534 & 12 & 2 & 16 \\
\hline LA 03217 E2 & 13 & 2 & 16 \\
\hline LA 03217D-P2 & 13 & 2 & 16 \\
\hline Magnolia & 13 & 2 & 16 \\
\hline Pavon 753 (Lr47) & 13 & 3 & 18 \\
\hline Trego & 14 & 2 & 17 \\
\hline Pavon76 & 14 & 3 & 19 \\
\hline LA 04041D-10 & 15 & 2 & 18 \\
\hline T177 & 15 & 3 & 19 \\
\hline T178 & 15 & 3 & 19 \\
\hline TAM 303 & 16 & 3 & 21 \\
\hline WGRC36 & 17 & 3 & 22 \\
\hline ARS05-0242 & 19 & 3 & 23 \\
\hline Total sensitive $^{\mathrm{d}}$ & $19(73 \%)$ & $24(92 \%)$ & $(96 \%)$ \\
\hline
\end{tabular}

${ }^{a}$ Counts include cultivars with a chlorotic (y) or necrotic (+) response at 7 days post-infiltration. Sensitivity determined by culture filtrate (CF) infiltration assay.

b Thirty-three southeastern U.S. S. nodorum isolates collected by Crook et al. (7) and three $S$. nodorum control isolates from North Dakota (19).

${ }^{c} S$. nodorum isolates plus $P$. pastoris controls. P. pastoris strains transformed for heterologous expression of SnToxA, SnTox1, and SnTox3.

${ }^{\mathrm{d}}$ Total sensitive cultivars. Of 26 tested cultivars, number and percent that showed sensitivity in at least one $\mathrm{CF}$ assay. 


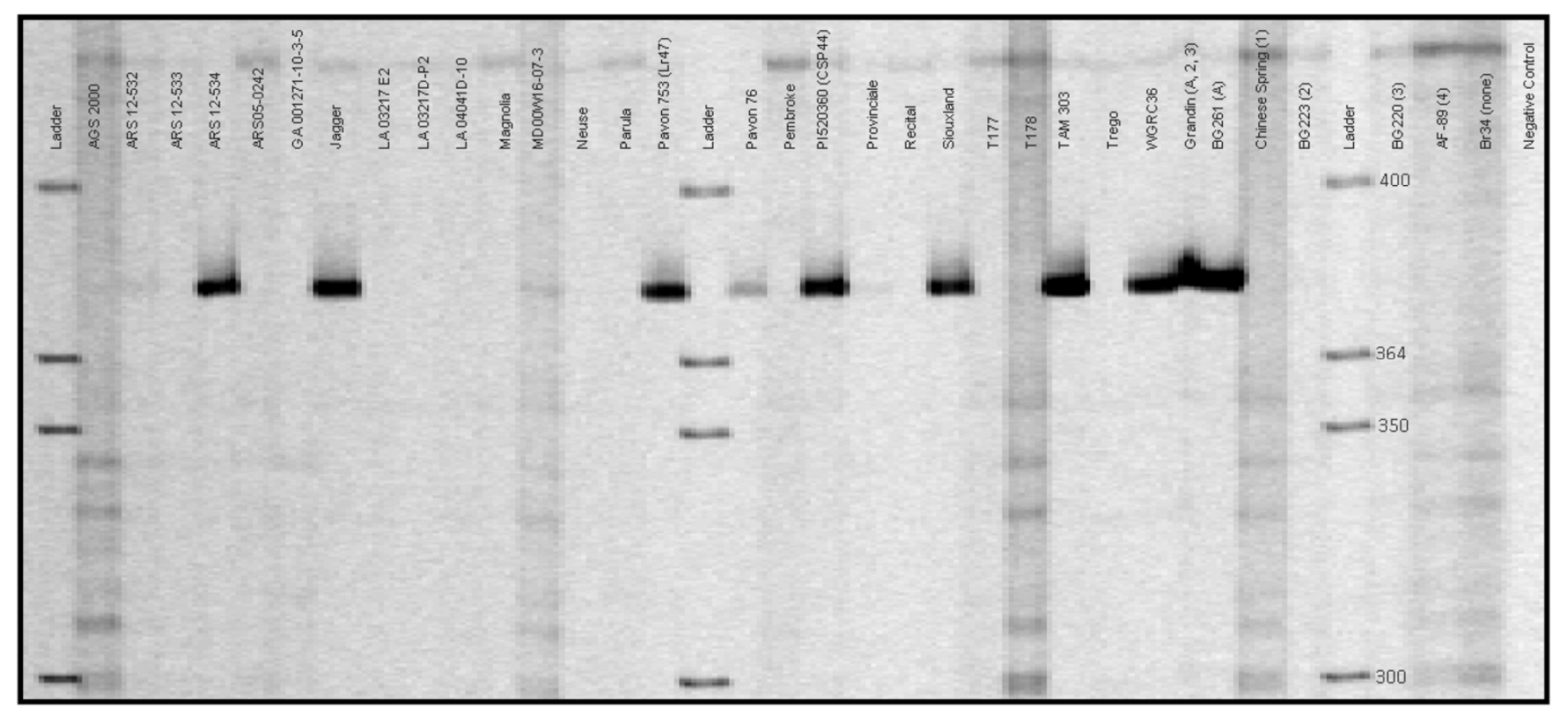

Fig. 2. Marker results in 33 wheat lines using Xfcp623 primers, which amplify a 380-bp fragment within the $T s n 1$ wheat gene for sensitivity to the SnToxA necrotrophic effector of Stagonospora nodorum. All cultivars that produced the 380-bp product were also sensitive to SnToxA produced by Pichia pastoris.

in play, such as varying levels of resistance to cell-wall-degrading enzymes, nonproteinaceous phytotoxins, or other types of effectors.

The field disease resistance scores are only comparable within a test, and the tests occurred in different years; thus, it was not possible to statistically evaluate the overall association of field disease severity and presence of Snn3 or Tsn1. However, possession of $T s n 1$ or $S n n 3$ did not always correspond to increased susceptibility. For example, among the three sister lines ARS 12-532, -533, and 534 , the most susceptible field response was in the line without either $S n n 3$ or $T s n 1$ (ARS 12-532), while the least susceptible line (ARS 12-534) had both Snn3 and Tsn1. Of course, Tsn1 and Snn3 are only expected to confer susceptibility if $S$. nodorum isolates present in the field possess the corresponding NEs.

A similar study was recently conducted in Western Australia, where SNB is a major problem (33). The researchers compared NE sensitivity with disease resistance scores in a set of 60 Australian bread wheats with varying levels of SNB susceptibility. They found that $87 \%$ of the lines were sensitive to SnTox3 and concluded that the SnTox3-Snn3 interaction was a major contributor to SNB susceptibility (33) in the germplasm collection, although the conclusion was questioned (10). The Australian study also found that $55 \%$ of the 60 wheat lines tested were sensitive to SnToxA. Global surveys have found that $96 \%$ of S. nodorum isolates in Australia contained SnTox3 (19) and 100\% contained SnToxA (30), although both conclusions are drawn from the same sample of 58 isolates collected from one field in 1 year. By comparison, of the 39 southeastern U.S. isolates from which the present isolates were selected, $38 \%$ possessed SnTox3 and 15\% carried SnToxA (7). The importance of the SnToxA-Tsnl and SnTox3-Snn3 interactions in eastern U.S. SNB epidemics and, thus, the priority of selecting against Tsn1 and Snn3 in wheat breeding merits further investigation.

In a recent review, Oliver et al. (24) summarized the mapping status of each host sensitivity gene: Tsn1 as "cloned", Snnl and Snn2 as "fine-mapped", and Snn3-5B as "mapped" (9,17,2426,34). The hallmark of a diagnostic molecular marker is consistent PCR-amplified products that are indicative of the presence or absence of a gene. In our study, 9 of the 10 investigated markers showed nondiagnostic polymorphism. Almost all of these markers were SSRs, which are highly variable regions of the wheat genome; therefore, the amplified product can vary in fragment size even with closely linked markers. It is also possible that recombination during meiosis occurred between the reported markers and the genes of interest. This likely accounts for the lack of agreement between the marker results and those from $\mathrm{CF}$ infiltrations.

Only Xfcp623, a perfect marker internal to the Tsn1 gene, gave results that matched those obtained from infiltration, providing two potential means of early-generation testing for SnToxA sensitivity. $X f c p 623$ is a dominant marker; thus, the amplified product is either present or absent with no variation in product size. Although no molecular marker was identified as diagnostic for Snn3, CF infiltration with the $P$. pastoris SnTox3 control strain was effective at detecting this gene. With the prevalence of Snn3 among the susceptible cultivars, breeders seeking to eliminate sources of SNB susceptibility could include early-generation testing to screen out Snn3 by infiltration assays. Breeders could make use of infiltrations, PCR amplification with markers, or both methods to effectively remove $T s n 1$ from wheat cultivars. However, given the low frequency of SnToxA in southeastern U.S. S. nodorum isolates, it remains unclear how important $T s n 1$-mediated susceptibility is in determining disease dynamics in this region. A larger survey of the southeastern U.S. S. nodorum population with respect to frequencies of SnToxA and SnTox3 is warranted.

In summary, we now know that Tsn1 and Snn3 are relatively common in southeastern U.S. wheat germplasm. We have confirmed the availability of tools to accurately screen for these sensitivity genes. Removal of host sensitivity genes from advanced cultivars should improve resistance to SNB and reduce yield losses due to this disease.

\section{Acknowledgments}

We thank all those who helped with the project: A. (Zearfoss) Crook, J. Faris, T. Friesen, E. Vargo, P. Labadie, and R. Parks.

\section{Literature Cited}

1. Abeysekara, N. S., Friesen, T. L., Keller, B., and Faris, J. D. 2009. Identification and characterization of a novel host-toxin interaction in the wheatStagonospora nodorum pathosystem. Theor. Appl. Genet. 120:117-126.

2. Arseniuk, E., Goral, T., and Scharen, A. L. 1998. Seasonal patterns of spore dispersal of Phaeosphaeria spp. and Stagonospora spp. Plant Dis. 82:187194.

3. Bent, A. F., and Mackey, D. 2007. Elicitors, effectors and $R$ genes: the new paradigm and a lifetime supply of questions. Annu. Rev. Phytopathol. 45:399-436.

4. Bergstrom, G. C. 2010. Stagonospora nodorum blotch and Stagonospora avenae blotch. Pages 75-77. in: Compendium of Wheat Diseases and Pests. W. W. Bockus, R. L. Bowden, R. M. Hunger, W. L. Morrill, T. D. Murray, and R. W. Smiley, eds. American Phytopathological Society, St. Paul, MN.

5. Bhathal, J. S., Loughman, R., and Speijers, J. 2003. Yield reduction in 
wheat in relation to leaf disease from yellow (tan) spot and Septoria nodorum blotch. Eur. J. Plant Pathol. 109:435-443.

6. Cowger, C., and Murphy, J. P. 2007. Artificial inoculation of wheat for selecting resistance to Stagonospora nodorum blotch. Plant Dis. 91:539-545.

7. Crook, A. D., Friesen, T. L., Liu, Z. H., Ojiambo, P. S., and Cowger, C. 2012. Novel necrotrophic effectors from Stagonospora nodorum and corresponding host sensitivities in winter wheat germplasm in the southeastern United States. Phytopathology 102:498-505.

8. Eyal, Z., Scharen, A. L., and Prescott, J. M. 1987. The Septoria Diseases of Wheat: Concepts and Methods of Disease Management. H. P. Hettel, ed. CIMMYT, Mexico, D.F.

9. Faris, J. D., Zhang, Z., Lu, H., Lu, S., Reddy, L., Cloutier, S., Fellers, J. P., Meinhardt, S. W., Rasmussen, J. B., Xu, S. S., Oliver, R. P., Simons, K. J., and Friesen, T. L. 2010. A unique wheat disease resistance-like gene governs effector-triggered susceptibility to necrotrophic pathogens. Proc. Natl. Acad. Sci. USA 107:13544-13549.

10. Francki, M. G. 2013. Improving Stagonospora nodorum resistance in wheat: a review. Crop Sci. 53:355-365.

11. Friesen, T. L., Chu, C. G., Liu, Z. H., Xu, S. S., Halley, S., and Faris, J. D. 2009. Host-selective toxins produced by Stagonospora nodorum confer disease susceptibility in adult wheat plants under field conditions. Theor. Appl. Genet. 118:1489-1497.

12. Friesen, T. L., and Faris, J. D. 2009. Characterization of the wheat-Stagonospora nodorum disease system: what is the molecular basis of this quantitative necrotrophic interaction? Can. J. Plant Pathol. 32:20-28.

13. Friesen, T. L., Faris, J. D., Chu, C., and Xu, S. S. 2012. SnTox5-Snn5: a novel Stagonospora nodorum effector-wheat gene interaction and its relationship with the SntoxA-Tsn1 and SnTox3-Snn3-B1 interactions. Mol. Plant Pathol. 13:1101-1109.

14. Friesen, T. L., Faris, J. D., Solomon, P. S., and Oliver, R. P. 2008. Hostspecific toxins: effectors of necrotrophic pathogenicity. Cell. Microbiol. 10:1421-1428

15. Friesen, T. L., Meinhardt, S. W., and Faris, J. D. 2007. The Stagonospora nodorum-wheat pathosystem involves multiple proteinaceous host-selective toxins and corresponding host sensitivity genes that interact in an inverse gene-for-gene manner. Plant J. 51:681-692.

16. Friesen, T. L., Stukenbrock, E. H., Liu, Z., Meinhardt, S. W., Ling, H., Faris, J. D., Rasmussen, J. B., Solomon, P. S., McDonald, B. A., and Oliver, R. P. 2006. Emergence of a new disease as a result of interspecific virulence gene transfer. Nat. Genet. 38:953-956.

17. Friesen, T. L., Zhang, Z., Solomon, P. S., Oliver, R. P., and Faris, J. D. 2008. Characterization of the interaction of a novel Stagonospora nodorum hostselective toxin with a wheat susceptibility gene. Plant Physiol. 146:682-693.

18. Liu, Z., Faris, J. D., Meinhardt, S. W., Ali, S., Rasmussen, J. B., and Friesen, T. L. 2004. Genetic and physical mapping of a gene conditioning sensitivity in wheat to a partially purified host-selective toxin produced by Stagonospora nodorum. Phytopathology 94:1056-1060.

19. Liu, Z., Faris, J. D., Oliver, R. P., Tan, K.-C., Solomon, P. S., McDonald, M. C., McDonald, B. A., Nunez, A., Lu, S., Rasmussen, J. B., and Friesen, T. L. 2009. SnTox3 acts in effector triggered susceptibility to induce disease on wheat carrying the Snn3 gene. PLoS Pathog. 5. Online publication. doi:10.1371/journal.ppat.1000581

20. Liu, Z., Zhang, Z., Faris, J. D., Oliver, R. P., Syme, R., McDonald, M. C., McDonald, B. A., Solomon, P. S., Lu, S., Shelver, W. L., Xu, S. S., and Friesen, T. L. 2012. The cysteine rich necrotrophic effector SnTox1 pro- duced by Stagonospora nodorum triggers susceptibility in wheat lines harboring Snn1. PLoS Pathog. 8:1-24.

21. Liu, Z. H., Anderson, J. A., Hu, J., Friesen, T. L., Rasmussen, J. B., and Faris, J. D. 2005. A wheat intervarietal genetic linkage map based on microsatellite and target region amplified polymorphism markers and its utility for detecting quantitative trait loci. Theor. Appl. Genet. 111:782-794.

22. Liu, Z. H., Friesen, T. L., Ling, H., Meinhardt, S. W., Oliver, R. P., Rasmussen, J. B., and Faris, J. D. 2006. The Tsn1-ToxA interaction in the wheatStagonospora nodorum pathosystem parallels that of the wheat-tan spot system. Genome 49:1265-1273.

23. Liu, Z. H., Friesen, T. L., Rasmussen, J. B., Ali, S., Meinhardt, S. W., and Faris, J. D. 2004. Quantitative trait loci analysis and mapping of seedling resistance to Stagonospora nodorum leaf blotch in wheat. Phytopathology 94:1061-1067.

24. Oliver, R. P., Friesen, T. L., Faris, J. D., and Solomon, P. S. 2012. Stagonospora nodorum: from pathology to genomics and host resistance. Annu. Rev. Phytopathol. 50:23-43.

25. Reddy, L., Friesen, T. L., Meinhardt, S. W., Chao, S., and Faris, J. D. 2008. Genomic analysis of the Snn1 locus on wheat chromosome arm 1BS and the identification of candidate genes Plant Genome 1:55-66.

26. Röder, M. S., Korzun, V., Wendehake, K., Plascke, J., Tixier, M.-H., Leroy, P., and Ganal, M. W. 1988. A microsatellite map of wheat. Genetics 149:2007-2023.

27. Solomon, P. S., Lowe, R. G. T., Tan, K. C., Waters, O. D. C., and Oliver, R. P. 2006. Stagonospora nodorum: cause of Stagonospora nodorum blotch of wheat. Mol. Plant Pathol. 7:147-156.

28. Sommerhalder, R. J., McDonald, B. A., Mascher, F., and Zhan, J. 2010. Sexual recombinants make a significant contribution to epidemics caused by the wheat pathogen Phaeosphaeria nodorum. Phytopathology 100:855-862.

29. Stein, N., Herren, G., and Keller, B. 2001. A new DNA extraction method for high-throughput marker analysis in large genome species such as Triticum aestivum. Plant Breed. 120:354-356.

30. Stukenbrock, E. H., and McDonald, B. A. 2007. Geographical variation and positive diversifying selection in the host-specific toxin SnToxA. Mol. Plant Pathol. 8:321-332.

31. Tan, K.-C., Ferguson-Hunt, M., Rybak, K., Waters, O. D. C., Stanley, W. A., Bond, C. S., H., S. E., Friesen, T. L., Faris, J. D., McDonald, B. A., and Oliver, R. P. 2012. Quantitative variation in effector activity of ToxA isoforms from Stagonospora nodorum and Pyrenophora tritici-repentis. Mol. PlantMicrobe Interact. 25:515-522.

32. Vereet, J. A., and Hoffman, G. M. 1990. A biologically oriented threshold decision model for control of epidemics of Septoria nodorum in wheat. Plant Dis. 74:731-738.

33. Waters, O. D. C., Lichtenzveig, J., Rybak, K., Friesen, T. L., and Oliver, R. P. 2011. Prevalence and importance of sensitivity to the Stagonospora nodorum necrotrophic effector SnTox3 in current Western Australian wheat cultivars. Crop Pasture Sci. 62:556-562.

34. Zhang, Z., Friesen, T. L., Simons, K. J., Xu, S. S., and Faris, J. D. 2009. Development, identification, and validation of markers for marker-assisted selection against the Stagonospora nodorum sensitivity genes Tsn1 and Snn2 in wheat. Mol. Breed. 23:35-49.

35. Zhang, Z., Friesen, T. L., Xu, S. S., Shi, G., Liu, Z., Rasmussen, J. B., and Faris, J. D. 2011. Two putatively homoeologous wheat genes mediate recognition of SnTox3 to confer effector-triggered susceptibility to Stagonospora nodorum. Plant J. 65:27-38. 